\title{
Hubungan Faktor Risiko dengan Infestasi Pediculus humanus capitis pada Anak Panti Asuhan di Kota Pekanbaru
}

\section{Relationship between Risk Factors and Pediculus humanus capitis Infestation in Children at Orphanages in Pekanbaru}

\author{
Esy Maryanti $^{1 *}$, Suri Dwi Lesmana ${ }^{1}$, Melia Novira ${ }^{2}$ \\ ${ }^{1} \mathrm{KJF}$ Parasitologi Fakultas Kedokteran Universitas Riau, ${ }^{2}$ Fakultas Kedokteran Universitas Riau
}

\begin{abstract}
ABSTRAK
Pedikulosis kapitis dikategorikan sebagai penyakit yang terabaikan dan masih menjadi masalah kesehatan. Infestasi Pediculus humanus capitis dengan mudah ditularkan melalui hubungan langsung antar individu atau benda pribadi yang digunakan bersama. Pedikulosis kapitis memiliki berbagai faktor risiko yang dapat meningkatkan terjadinya infestasi Pediculus humanus capitis. Penyakit ini menyerang semua usia terutama usia muda dan cepat meluas dalam lingkungan hidup yang padat seperti asrama dan panti asuhan. Gejala klinis yang khas berupa gatal disertai adanya bekas garukan. Tujuan dari penelitian ini untuk mengetahui hubungan faktor risiko dengan infestasi Pediculus humanus capitis pada anak panti asuhan di kota Pekanbaru. Anak panti asuhan yang diperiksa berjumlah 127 orang dari 3 panti asuhan di Pekanbaru. Hasil pemeriksaan didapatkan infestasi Pediculus humanus capitis pada perempuan lebih tinggi $(87,1 \%)$, infestasi berdasarkan kelompok usia lebih banyak terjadi pada usia 6-12 tahun (65,9\%), infestasi Pediculus humanus capitis menurut karakteristik rambut tertinggi pada keriting $(81,8 \%)$. Anak yang memiliki panjang rambut $>$ sebahu adalah $91,3 \%$. Kebiasaan anak yang selalu memakai alat rambut dan tidur bersama memiliki infestasi Pediculus humanus capitis sebesar $57,5 \%$ dan infestasi Pediculus humanus capitis untuk anak yang mencuci rambut $\geq 3$ kali seminggu adalah $58,3 \%$. Jenis kelamin dan karakteristik rambut memiliki hubungan yang signifikan mempengaruhi kejadian pedikulosis kapitis dengan nilai $p<0,05$.
\end{abstract}

Kata kunci: anak, faktor risiko, panti asuhan, Pediculus humanus capitis

\begin{abstract}
Pediculosis capitis is categorized as a neglected disease and it's still become a problem for public health. Pediculus humanus capitis infestation is easily transmitted directly between individuals or personal objects used together. Pediculosis capitis has various risk factors that can increase the occurrence of Pediculus humanus capitis infestation. The disease affects all ages especially juvenile and rapidly expands in dense living environment such as dormitories and orphanages. The specific symptom is itching accompanied by scratch mark. The purpose of this study is to determine the relationship between risk factors and pediculus humanus capitis infestation in children at orphanages in Pekanbaru. 127 children from 3 orphanages in Pekanbaru were examined. The results showed that Pediculus humanus capitis infestation is higher among girls (87,1\%) and the highest age group was 6-12 years (65,9\%). Curly hair is the highest hair characteristics (81,8\%). Children with hair length extend to the shoulder were $91,3 \%$. According to hygiene behaviours, children who exchange hair tools and sleep together were $57,5 \%$. Children who wash their hair 3 times or more a week is 58,3\%. Gender and hair characteristics had a significant relationship with pediculosis capitis $(p<0,05)$.

Keywords: children, orphanage, Pediculus humanus capitis, risk factor
\end{abstract}

*Korespondensi: Esy Maryanti, email: esy.maryanti@gmail.com

Artikel info: Online published first 25 April 2018; Received 30 Desember 2017; Accepted 17 Februari 2018.

DOI: https://doi.org/10.26891/jkm.v1i2.2018.73-80

Copyright @ 2018 Esy Maryanti, Suri Dwi Lesmana, Melia Novira. This is an open access article distributed under the terms of the Creative Commons Attribution-NonCommercial 4.0 International License (http://creativecommons.org/licenses/by-nc/4.0/), which permits unrestricted non-commercial use, distribution, and reproduction in any medium, provided the original author and source are properly cited. 
Pedikulosis kapitis adalah salah satu penyakit kulit/rambut kepala yang disebabkan oleh infestasi parasit berupa tuma Pediculus humanus capitis (P.h. capitis). ${ }^{1}$ Penyakit akibat infestasi P.h. capitis ini masih dikategorikan sebagai penyakit yang terabaikan (neglected disease) di negara miskin dan negara-negara berkembang serta masih menjadi masalah kesehatan. Setiap tahunnya terjadi peningkatan kasus infestasi P.h. capitis di negara tersebut. ${ }^{2,3}$

Pediculus humanus capitis merupakan ektoparasit yang bersifat kosmopolitan sehingga parasit ini dapat ditemukan infestasinya di seluruh dunia, terutama di daerah beriklim dingin yang penduduknya sering berpakaian tebal, jarang mandi, dan kurang menjaga kebersihan badannya. Infestasi P.h. capitis dapat dengan mudah ditularkan melalui hubungan langsung antar individu atau melalui benda-benda pribadi yang digunakan bersamasama. ${ }^{4}$ Penyakit pedikulosis kapitis dapat menyerang semua usia terutama anak-anak usia muda dan cepat meluas dalam lingkungan hidup yang padat, seperti di asrama dan panti asuhan. ${ }^{1}$ Pedikulosis kapitis juga memiliki berbagai faktor risiko yang dapat meningkatkan terjadinya infestasi P.h. capitis. $^{5}$ Hasil penelitian oleh Nindia $Y$ tahun 2016 menyatakan bahwa infestasi P.h. capitis dapat meningkat penularannya dengan berbagai faktor risiko, seperti karakteristik rambut, kebiasaan tidur bersama, dan memiliki saudara kandung yang terinfestasi P.h. capitis. ${ }^{6}$ Centers for Disease Control and Prevention (CDC) pada tahun 2016 menyatakan bahwa infestasi P.h. capitis tersebar di seluruh dunia dengan angka kejadian terbanyak pada anak usia 3 sampai 11 tahun. ${ }^{7}$ Penelitian di Amerika Serikat yang dilakukan pada anak usia sekolah dan pra sekolah didapatkan 6 juta sampai 12 juta terinfestasi P.h. capitis terutama pada anak perempuan usia 3 sampai 11 tahun. ${ }^{8}$ Infestasi yang sangat tinggi dilaporkan lebih dari $70 \%$ terjadi di Pakistan pada tahun $2015 .{ }^{9}$ Hal yang sama juga terjadi di negara Indonesia pada tahun 2016 dengan angka kejadian infestasi P.h. capitis $27,1 \%$ pada murid sekolah dasar di kota Sabang Provinsi Aceh. ${ }^{6}$ Penelitian serupa juga dilakukan di Provinsi Riau pada tahun 2009 dengan hasil 39,3\% terinfestasi P.h. capitis. ${ }^{10}$

Pada penelitian tersebut di atas, tergambar bahwa infestasi P.h. capitis banyak terjadi pada anak-anak usia muda terutama usia 3 - 11 tahun. Infestasi P.h. capitis pada rambut/kulit kepala anak dapat menimbulkan berbagai gejala klinis. Gejala klinis yang khas berupa gatal-gatal disertai adanya bekas garukan. ${ }^{4}$ Diagnosis dapat ditegakkan melalui pemeriksaan langsung atau dengan menggunakan sisir serit pada rambut/kulit kepala penderita dengan menemukan P.h. capitis dewasa, nimfa atau telur. ${ }^{11}$

Akibat dampak buruk yang bisa terjadi seperti kurangnya konsentrasi anak dalam belajar dan susah tidur oleh karena infestasi P.h. capitis dan masih jarangnya dilakukan penelitian tentang pedikulosis kapitis, maka hal ini harus mendapat perhatian terutama pada daerah yang berisiko sebagai tempat berkembang dan terjadinya penularan dari P.h. capitis.

Panti asuhan di Kota Pekanbaru merupakan salah satu tempat yang berisiko terhadap infestasi P.h. capitis. Berdasarkan hasil observasi lokasi yang dilakukan pada tiga panti asuhan di Pekanbaru yaitu, Panti Asuhan X dan Z pada September tahun lalu, serta Panti Asuhan Y pada Mei 2017 didapatkan ketiga panti asuhan ini memiliki faktor risiko infestasi P.h. capitis, seperti masih banyaknya anak panti asuhan yang memiliki rambut panjang, jarang mencuci rambut, tidur dengan menggunakan bantal yang sama, dan masih menggunakan alat atau aksesoris rambut bersama.

Berdasarkan latar belakang di atas, maka peneliti tertarik untuk melakukan penelitian tentang hubungan faktor risiko dengan infestasi P.h. capitis pada anak Panti Asuhan di Kota Pekanbaru.

\section{METODE}

Jenis penelitian ini adalah analitik yang akan dilakukan analisis hubungan faktor risiko dengan infestasi Pediculus humanus capitis pada anak panti asuhan di kota Pekanbaru. Penelitian di lakukan pada bulan Juni hingga Desember 2017. Pemeriksaan infestasi Pediculus humanus capitis dilakukan di tiga panti asuhan di kota Pekanbaru yaitu Panti Asuhan X, Y, dan Z dengan total anak yang diperiksa 127 orang. Penelitian ini dimulai dengan memberikan pengarahan kepada anak panti asuhan dan memberikan kertas

informed consent yang diisi oleh pemilik atau pengasuh anak panti asuhan. Sebelum dilakukan pemeriksaan, peneliti akan melakukan wawancara terpimpin kepada setiap responden. Selanjutnya dilakukan pemeriksaan untuk menilai jenis rambut dan panjang rambut. Setelah itu baru dilakukan pemeriksaan langsung pada kepala setiap responden dengan pengamatan terlebih dahulu untuk melihat apakah ada telur kutu pada rambut responden tersebut. Selanjutnya baru menggunakan sisir serit untuk menemukan nimfa dan kutu rambut dewasa. 
Penelitian ini dilakukan pada tiga panti asuhan di Pekanbaru, yaitu Panti Asuhan X, Y, dan Z. Sampel berjumlah 127 orang anak yang terdiri dari 30 orang anak Panti Asuhan X, 57 orang anak Panti Asuhan Y, dan 40 orang anak Panti Asuhan Z. Karakteristik anak Panti Asuhan tersebut dapat dilihat pada Tabel 1.

Tabel 1. Distribusi frekuensi faktor risiko P.h. capitis $(\mathrm{N}=127)$

\begin{tabular}{|c|c|c|c|c|c|c|c|c|}
\hline \multirow{3}{*}{$\begin{array}{l}\text { Karakteristik } \\
\text { faktor risiko }\end{array}$} & \multicolumn{6}{|c|}{ Panti Asuhan Pekanbaru } & \multirow{2}{*}{\multicolumn{2}{|c|}{ Jumlah }} \\
\hline & \multicolumn{2}{|c|}{$\mathrm{X}$} & \multicolumn{2}{|c|}{$\mathrm{Y}$} & \multicolumn{2}{|c|}{ Z } & & \\
\hline & $\mathrm{N}$ & $\%$ & $\mathrm{~N}$ & $\%$ & $\mathrm{~N}$ & $\%$ & $\mathrm{~N}$ & $\%$ \\
\hline \multicolumn{9}{|l|}{ Usia } \\
\hline - $1-5$ tahun & 3 & 2,36 & 3 & 2,36 & 1 & 0,78 & 7 & 5,5 \\
\hline - 6-12 tahun & 12 & 9,45 & 17 & 13,4 & 12 & 9,45 & 41 & 32,3 \\
\hline - 13-18 tahun & 15 & 11,8 & 37 & 29,1 & 27 & 21,3 & 79 & 62,2 \\
\hline \multicolumn{9}{|l|}{ Jenis kelamin } \\
\hline - Laki-laki & 15 & 11,8 & 35 & 27,6 & 15 & 11,8 & 65 & 51,2 \\
\hline - Perempuan & 15 & 11,8 & 22 & 17,3 & 25 & 19,7 & 62 & 48,8 \\
\hline \multicolumn{9}{|l|}{ Jenis rambut } \\
\hline - Lurus & 21 & 16,5 & 42 & 33,1 & 27 & 21,3 & 90 & 70,8 \\
\hline - Ikal & 5 & 3,9 & 11 & 8,7 & 10 & 7,9 & 26 & 20,5 \\
\hline - Keriting & 4 & 3,15 & 4 & 3,15 & 3 & 2,36 & 11 & 8,7 \\
\hline \multicolumn{9}{|l|}{ Panjang rambut } \\
\hline - $\leq$ sebahu & 18 & 14,2 & 41 & 32,3 & 22 & 17,3 & 81 & 63,8 \\
\hline - > sebahu & 12 & 9,45 & 16 & 12,59 & 18 & 14,17 & 46 & 36,2 \\
\hline \multicolumn{9}{|l|}{ Frekuensi cuci rambut } \\
\hline - $\geq 3$ kali & 19 & 15 & 29 & 22,8 & 24 & 18,9 & 72 & 56,7 \\
\hline - <3kali & 11 & 8,7 & 28 & 22 & 16 & 12,6 & 55 & 43,3 \\
\hline \multicolumn{9}{|l|}{$\begin{array}{l}\text { Pemakaian alat } \\
\text { rambut bersama }\end{array}$} \\
\hline - Pernah & 30 & 23,6 & 57 & 44,9 & 40 & 31,5 & 127 & 100 \\
\hline - Tidak pernah & 0 & 0 & 0 & 0 & 0 & 0 & 0 & 0 \\
\hline \multicolumn{9}{|l|}{ Kebiasaan tidur } \\
\hline - Pernah & 30 & 23,6 & 57 & 44,9 & 40 & 31,5 & 127 & 100 \\
\hline - Tidak pernah & 0 & 0 & 0 & 0 & 0 & 0 & 0 & 0 \\
\hline
\end{tabular}

Berdasarkan Tabel 1 terlihat bahwa jumlah anak panti asuhan laki-laki dan perempuan hampir sama. Anak yang ikut dalam penelitian berada pada rentang usia 1-18 tahun dengan anak terbanyak berada pada kelompok usia 13-18 tahun yaitu sebanyak 79 anak (62,2\%).

Hasil pemeriksaan pada rambut/kulit kepala di Panti Asuhan di Kota Pekanbaru yang dilakukan oleh peneliti terhadap 127 orang anak didapatkan angka kejadian infestasi P.h. capitis dilihat pada Tabel 2.

Tabel 2. Distribusi frekuensi infestasi P.h. capitis pada anak Panti Asuhan di Kota Pekanbaru

\begin{tabular}{|c|c|c|c|c|c|c|c|c|}
\hline \multirow{3}{*}{$\begin{array}{l}\text { Infestasi } \\
\text { P.h. capitis }\end{array}$} & \multicolumn{6}{|c|}{ Panti Asuhan Pekanbaru } & \multirow{2}{*}{\multicolumn{2}{|c|}{ Jumlah }} \\
\hline & \multicolumn{2}{|c|}{$\mathrm{X}$} & \multicolumn{2}{|c|}{$\mathrm{Y}$} & \multicolumn{2}{|c|}{$Z$} & & \\
\hline & $\mathbf{N}$ & $\%$ & $\mathbf{N}$ & $\%$ & $\mathbf{N}$ & $\%$ & $\mathbf{N}$ & $\%$ \\
\hline Positif & 25 & 19,7 & 20 & 15,7 & 28 & 22,1 & 73 & $\mathbf{5 7 , 5}$ \\
\hline Negatif & 5 & 3,9 & 37 & 29,1 & 12 & 9,5 & 54 & 42,5 \\
\hline Total & 30 & 23,6 & 57 & 44,8 & 40 & 31,6 & 127 & 100 \\
\hline
\end{tabular}

Berdasarkan Tabel 2 dapat diketahui bahwa angka kejadian infestasi P.h. capitis sebesar $57,5 \%$ yaitu 73 orang anak dari total 127 orang anak yang diteliti.

Angka kejadian tertinggi terjadi di Panti Asuhan Z yaitu sebesar $22,1 \%$.
Tabel 3. Karakteristik anak yang terinfestasi $P$.h. capitis

\begin{tabular}{|c|c|c|c|c|c|c|c|c|c|c|}
\hline \multirow{4}{*}{$\begin{array}{l}\text { Karakteristik } \\
\text { faktor risiko }\end{array}$} & \multicolumn{6}{|c|}{ Infestasi P.h. capitis } & \multicolumn{4}{|c|}{ Jumlah } \\
\hline & \multicolumn{2}{|c|}{$\mathbf{X}$} & \multicolumn{2}{|c|}{$\mathbf{Y}$} & \multicolumn{2}{|c|}{$\mathbf{Z}$} & \multirow{2}{*}{\multicolumn{2}{|c|}{+}} & \multirow{2}{*}{\multicolumn{2}{|c|}{ - }} \\
\hline & + & - & + & - & + & - & & & & \\
\hline & $\mathbf{N}$ & $\mathbf{N}$ & $\mathbf{N}$ & $\mathbf{N}$ & $\mathbf{N}$ & $\mathbf{N}$ & $\mathbf{N}$ & $\%$ & $\mathbf{N}$ & $\%$ \\
\hline \multicolumn{11}{|l|}{ 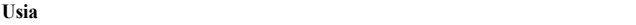 } \\
\hline - $1-5$ tahun & 3 & 0 & 0 & 3 & 1 & 0 & 4 & 57,1 & 3 & 42,9 \\
\hline - 6-12 tahun & 10 & 2 & 7 & 10 & 10 & 2 & 27 & 65,9 & 14 & 34,1 \\
\hline - 13-18 tahun & 12 & 3 & 13 & 24 & 17 & 10 & 42 & 53,2 & 37 & 46,8 \\
\hline \multicolumn{11}{|l|}{ Jenis kelamin } \\
\hline - Laki-laki & 10 & 5 & 3 & 32 & 6 & 9 & 19 & 29,2 & 46 & 70,8 \\
\hline - Perempuan & 15 & 0 & 17 & 5 & 22 & 3 & 54 & 87,1 & 8 & 12,9 \\
\hline \multicolumn{11}{|l|}{ Jenis rambut } \\
\hline - Lurus & 16 & 5 & 11 & 31 & 17 & 10 & 44 & 48,9 & 46 & 51,1 \\
\hline - Ikal & 5 & 0 & 6 & 5 & 9 & 1 & 20 & 76,9 & 6 & 23,1 \\
\hline - Keriting & 4 & 0 & 3 & 1 & 2 & 1 & 9 & 81,8 & 2 & 18,2 \\
\hline \multicolumn{11}{|l|}{ Panjang rambut } \\
\hline - $\leq$ sebahu & 13 & 5 & 7 & 34 & 11 & 11 & 31 & 38,3 & 50 & 61,7 \\
\hline - > sebahu & 12 & 0 & 13 & 3 & 17 & 1 & 42 & 91,3 & 4 & 8,7 \\
\hline \multicolumn{11}{|l|}{ Frekuensi cuci rambut } \\
\hline - $\quad \geq 3$ kali & 16 & 3 & 12 & 17 & 14 & 10 & 42 & 58,3 & 30 & 41,7 \\
\hline - $\quad<3$ kali & 9 & 2 & 8 & 20 & 14 & 2 & 31 & 56,4 & 24 & 43,6 \\
\hline \multicolumn{11}{|l|}{$\begin{array}{l}\text { Pemakaian alat } \\
\text { rambut bersama }\end{array}$} \\
\hline - Pernah & 25 & 5 & 20 & 37 & 28 & 12 & 73 & 57,5 & 54 & 42,5 \\
\hline - Tidak pernah & 0 & 0 & 0 & 0 & 0 & 0 & 0 & 0 & 0 & 0 \\
\hline \multicolumn{11}{|l|}{ Kebiasaan tidur } \\
\hline - Pernah & 25 & 5 & 20 & 37 & 28 & 12 & 73 & 57,5 & 54 & 42,5 \\
\hline - Tidak pernah & 0 & 0 & 0 & 0 & 0 & 0 & 0 & 0 & 0 & 0 \\
\hline
\end{tabular}

Berdasarkan Tabel 3 dapat diketahui bahwa kelompok usia yang lebih banyak terinfestasi P.h. capitis yaitu pada kelompok usia 6-12 tahun $(65,9 \%)$. Anak perempuan lebih banyak yang terinfestasi P.h. capitis yaitu berjumlah 54 anak (87,1\%), sedangkan laki-laki berjumlah lebih sedikit yaitu 19 anak $(29,2 \%)$. Infestasi P.h. capitis lebih tinggi pada jenis rambut keriting yaitu berjumlah 9 anak $(81,8 \%)$. Anak yang memiliki panjang rambut lebih dari sebahu lebih banyak yang terinfestasi P.h. capitis yaitu berjumlah 42 anak (91,3\%). Anak yang terinfestasi P.h. capitis yang membersihkan rambutnya $\geq 3$ kali dalam seminggu sebanyak 42 anak (58,3\%), sedangkan yang membersihkan rambut < 3 kali dalam seminggu berjumlah 31 anak $(56,4 \%)$. Anak panti asuhan yang menggunakan alat rambut/aksesoris rambut bersama dan memiliki kebiasaan tidur bersama terinfestasi P.h. capitis sebanyak 73 anak dengan persentase $57,5 \%$.

Hubungan faktor risiko dengan infestasi P.h. capitis pada anak Panti Asuhan di Kota Pekanbaru

Tabel 4. Hubungan usia dengan infestasi P.h. capitis

\begin{tabular}{|c|c|c|c|c|c|c|c|}
\hline \multirow{3}{*}{ Usia } & \multicolumn{4}{|c|}{$\begin{array}{c}\text { Infestasi } \\
\text { P.h. capitis }\end{array}$} & \multirow{2}{*}{\multicolumn{2}{|c|}{ Jumlah }} & \multirow{3}{*}{$\begin{array}{c}\mathrm{P} \\
\text { value }\end{array}$} \\
\hline & \multicolumn{2}{|c|}{ Positif } & \multicolumn{2}{|c|}{ Negatif } & & & \\
\hline & $\mathrm{N}$ & $\%$ & $\mathrm{~N}$ & $\%$ & $\mathrm{~N}$ & $\%$ & \\
\hline 1-5 tahun & 4 & 57,1 & 3 & 42,9 & 7 & 100 & 0,442 \\
\hline 6-12 tahun & 27 & 65,9 & 14 & 34,1 & 41 & 100 & \\
\hline 13-18 tahun & 42 & 53,2 & 37 & 46,8 & 79 & 100 & \\
\hline
\end{tabular}

Berdasarkan Tabel 4, hasil uji statistik chi square didapatkan nilai $P$ value sebesar 0,442 ( $p>0,05)$. Hal ini menunjukkan bahwa tidak terdapat hubungan 
yang signifikan antara usia dengan infestasi P.h. capitis.

Tabel 5. Hubungan jenis kelamin dengan infestasi P.h. capitis

\begin{tabular}{lcccccccc}
\hline & \multicolumn{4}{c}{ Infestasi } & & & \\
& \multirow{3}{*}{ Jenis kelamin capitis } & Jumlah & OR & $\begin{array}{c}\mathrm{P} \\
\text { value }\end{array}$ \\
\cline { 2 - 6 } & \multicolumn{2}{c}{ Positif } & \multicolumn{2}{c}{ Negatif } & & & & \\
\cline { 2 - 7 } & $\mathrm{N}$ & $\%$ & $\mathrm{~N}$ & $\%$ & $\mathrm{~N}$ & $\%$ & & \\
\hline Laki-laki & 19 & 29,2 & 46 & 70,8 & 65 & 100 & 6,9 & 0,000 \\
Perempuan & 54 & 87,1 & 8 & 12,9 & 62 & 100 & & \\
\hline
\end{tabular}

Berdasarkan Tabel 5, hasil uji statistik chi square didapatkan nilai $P$ value sebesar $0,000(p<0,05)$. Hal ini menunjukkan bahwa terdapat hubungan yang signifikan antara jenis kelamin dengan infestasi P.h. capitis.

Tabel 6. Hubungan karakteristik jenis rambut dengan infestasi P.h. capitis

\begin{tabular}{lcccccccc}
\hline & \multicolumn{3}{c}{ Infestasi } & & & \\
\multirow{3}{*}{ Karakteristik jenis rambut } & \multicolumn{3}{c}{ P.hapitis } & Jumlah & OR & P value \\
\cline { 2 - 6 } & \multicolumn{3}{c}{ Positif } & Negatif & & & & \\
\cline { 2 - 7 } & $\mathrm{N}$ & $\%$ & $\mathrm{~N}$ & $\%$ & $\mathrm{~N}$ & $\%$ & & \\
\hline Lurus & 44 & 48,9 & 46 & 51,1 & 90 & 100 & 2,6 & 0,009 \\
Ikal & 20 & 76,9 & 6 & 23,1 & 26 & 100 & & \\
Keriting & 9 & 81,8 & 2 & 18,2 & 11 & 100 & & \\
\hline
\end{tabular}

Berdasarkan Tabel 6, hasil uji statistik chi square didapatkan nilai $P$ value sebesar $0,009(p<0,05)$. Hal ini menunjukkan bahwa terdapat hubungan yang signifikan antara jenis rambut dengan infestasi $P . h$. capitis.

Tabel 7. Hubungan karakteristik panjang rambut dengan infestasi P.h. capitis

\begin{tabular}{|c|c|c|c|c|c|}
\hline \multirow{4}{*}{ Karakteristik panjang rambut } & & & \multirow{3}{*}{ Jumlah } & \multirow{3}{*}{ OR } & \multirow{3}{*}{ P value } \\
\hline & \multicolumn{2}{|c|}{ P.h. capitis } & & & \\
\hline & Positif & Negatif & & & \\
\hline & $\mathrm{N} \quad \%$ & $\mathrm{~N} \quad \%$ & $\mathrm{~N} \quad \%$ & & \\
\hline$\leq$ sebahu & $\begin{array}{ll}31 & 38,3\end{array}$ & $\begin{array}{ll}50 & 61,7\end{array}$ & $81 \quad 100$ & 3,5 & 0,000 \\
\hline$>$ sebahu & 4291,3 & $\begin{array}{ll}4 & 8,7\end{array}$ & $\begin{array}{ll}46 & 100\end{array}$ & & \\
\hline
\end{tabular}

Berdasarkan Tabel 7, hasil uji statistik chi square didapatkan nilai $P$ value sebesar $0,000(p<0,05)$. Hal ini menunjukkan bahwa terdapat hubungan yang signifikan antara panjang rambut dengan infestasi P.h. capitis.

Tabel 8. Hubungan frekuensi cuci rambut dengan infestasi P.h. capitis

\begin{tabular}{|c|c|c|c|c|c|c|c|}
\hline \multirow{4}{*}{ Frekuensi cuci rambut } & \multicolumn{4}{|c|}{ Infestasi } & \multirow{3}{*}{\multicolumn{2}{|c|}{ Jumlah }} & \multirow{3}{*}{$\mathrm{P}$ value } \\
\hline & \multicolumn{4}{|c|}{ P.h. capitis } & & & \\
\hline & \multicolumn{2}{|c|}{ Positif } & \multicolumn{2}{|c|}{ Negatif } & & & \\
\hline & $\mathrm{N}$ & $\%$ & $\mathrm{~N}$ & $\%$ & $\mathrm{~N}$ & $\%$ & \\
\hline \multirow{2}{*}{$\begin{array}{l}\geq 3 \text { kali seminggu } \\
<3 \text { kali seminggu }\end{array}$} & 42 & 58,3 & 30 & 41,7 & 72 & 100 & 0,824 \\
\hline & 31 & 56,4 & 24 & 43,6 & 55 & 100 & \\
\hline
\end{tabular}

Berdasarkan Tabel 8, hasil uji statistik chi square didapatkan nilai $P$ value sebesar 0,0824 $(p>0,05)$. $\mathrm{Hal}$ ini menunjukkan bahwa tidak terdapat hubungan yang signifikan antara frekuensi cuci rambut dengan infestasi P.h. capitis. Hasil uji statistik chi square terhadap kebiasaan tidur bersama dan pemakaian alat rambut/aksesoris rambut bersama tidak dapat dinilai pengaruhnya karena tidak memenuhi syarat tabel chi square $2 \times 2$. Hal ini dikarenakan semua anak panti asuhan pernah tidur bersama dan menggunakan alat rambut/aksesoris rambut bersama.

Penelitian ini dilakukan terhadap 127 anak di 3 Panti Asuhan di Kota Pekanbaru yaitu Panti Asuhan X,Y, dan Z. Sampel terdiri dari 30 anak Panti Asuhan X, 57 anak Panti Asuhan Y, dan 40 anak Panti Asuhan Z di Kota Pekanbaru yang sesuai dengan proporsi tiaptiap panti asuhan. Anak yang dijadikan sampel dalam penelitian ini berada pada rentang usia 1-18 tahun dengan anak terbanyak berada pada kelompok usia 13-18 tahun. Salah satu panti asuhan di kota Bandung yaitu Panti Sosial Asuhan Anak Wisma Putra Bandung juga memiliki jumlah penghuni remaja paling banyak yaitu 70 remaja dari 80 jumlah keseluruhan penghuninya. Penghuni remaja mendominasi di Lembaga Kesejahteraan Sosial Anak (LKSA) di berbagai daerah di Indonesia. ${ }^{12} \mathrm{Hal}$ ini sesuai dengan tujuan LKSA dalam mewujudkan pemenuhan hak dasar anak (usia $<18$ tahun) untuk tinggal di panti asuhan sampai lulus Sekolah Lanjutan Tingkat Atas (SLTA). ${ }^{13}$

Jumlah anak panti asuhan laki-laki hampir sama dengan anak perempuan yaitu laki-laki 65 anak dan perempuan 62 anak. Jenis rambut anak panti asuhan terdiri dari lurus, ikal, dan keriting. Jenis rambut terbanyak adalah lurus yaitu sebanyak 90 anak $(70,9 \%)$. Jenis rambut lurus ini sesuai dengan ciri khas ras yang ada di Indonesia yaitu mongoloid. A.L. Kroeber yang mengklasifikasikan ras di dunia menjadi 3 bagian yaitu kaukasoid, mongoloid, dan negroid menyatakan bahwa ras mongoloid memiliki karakteristik salah satunya berupa rambut hitam yang dominannya adalah lurus, diikuti dengan bergelombang (ikal), dan keriting.

Anak panti asuhan yang memiliki panjang rambut $\leq$ sebahu lebih banyak yaitu 81 anak (63,8\%) dibandingkan dengan anak yang memiliki rambut $>$ sebahu yaitu 46 anak (36,2\%). Ini dikarenakan jumlah anak laki-laki yang hampir sama dengan perempuan. Perilaku higiene anak panti asuhan seperti frekuensi cuci rambut dalam seminggu yaitu 72 anak $(56,7 \%)$ telah mencuci rambut $\geq 3$ kali, 
sedangkan 55 anak (43,3\%) masih mencuci rambut < 3 kali dalam seminggu. Hal ini dikarenakan pada setiap panti asuhan telah disiapkan shampo untuk anak-anak panti agar dapat membersihkan rambutnya, sehingga tidak perlu lagi untuk membeli secara individu. Semua anak Panti Asuhan di Kota Pekanbaru masih menggunakan alat rambut/aksesoris rambut secara bersamaan serta masih tidur bersama. Beberapa faktor inilah yang nantinya akan dapat menyebabkan terjadinya peningkatan infestasi P.h. capitis pada anak Panti Asuhan di Kota Pekanbaru.

Angka kejadian infestasi P.h. capitis pada penelitian yang telah dilakukan didapatkan infestasi yang tinggi yaitu sebesar $57,5 \%$. Angka tersebut jauh lebih tinggi jika dibandingkan dengan penelitian Zulinda ${ }^{10}$ pada tahun 2009 di Kecamatan Rumbai Pesisir Pekanbaru yaitu sebesar $39,3 \%$ dan penelitian Zhen $\mathrm{AJ}^{14}$ di Yogyakarta tahun 2011 yaitu 12,3\% serta penelitian oleh Munusamy $\mathrm{H}^{15}$ di Yogyakarta tahun 2011 yaitu 19,6\%. Angka kejadian infestasi P.h. capitis ada penelitian ini tidak jauh berbeda dengan penelitian Rahman $Z^{16}$ yang dilakukan di Semarang pada tahun 2014 yaitu sebesar 59,3\%. Angka kejadian pedikulosis kapitis pada penelitian ini lebih rendah jika dibandingkan dengan beberapa penelitian lain, seperti penelitian yang dilakukan oleh Akhmad AM di Jakarta tahun 2012 yaitu sebesar 100\% terinfestasi P.h. capitis . ${ }^{17}$

Infestasi kutu kepala dilaporkan masih menjadi masalah kesehatan pada anak-anak diberbagai negara di dunia dengan angka kejadian bervariasi mulai dari $0,7 \%$ - $59 \%$ bahkan dapat dijumpai dengan infestasi yang sangat tinggi yaitu lebih dari $70 \%{ }^{9}$ Hal ini menunjukkan masih rendahnya pengetahuan masyarakat terhadap penyakit pedikulosis kapitis yaitu dari penanganan kejadian pedikulosis, metode pemberantasan, banyaknya kontak langsung, tingkat higiene perorangan, dan keadaan tempat tinggal yang dapat meningkatkan infestasi P.h. capitis. ${ }^{15}$

Tingginya angka kejadian infestasi P.h. capitis di berbagai tempat disebabkan oleh berbagai faktor risiko diantaranya perilaku higiene, karakteristik rambut, dan keadaan geografis wilayah penelitian. Kota Pekanbaru merupakan daerah yang dilalui garis khatulistiwa dengan suhu maksimal 34,1으 - 35,6ㅇ C sedangkan suhu minimal $20,2{ }^{\circ} \mathrm{C}-23,0{ }^{\circ} \mathrm{C} .{ }^{18}$ Kondisi suhu lingkungan inilah yang sangat optimal bagi siklus hidup atau perkembangbiakan dari telur P.h. capitis yaitu antara $29 \circ \mathrm{C}-32{ }^{\circ} \mathrm{C} .{ }^{19}$ Selain kondisi suhu, lingkungan yang padat dan kurangnya kepedulian terhadap penularan infestasi P.h. capitis juga mempengaruhi angka kejadian dari pedikulosis kapitis. $^{1}$

Infestasi P.h. capitis berdasarkan kelompok usia memperlihatkan bahwa lebih banyak terjadi pada anak dengan kelompok usia 6-12 tahun $(65,9 \%)$. Penelitian ini sejalan dengan penelitian di Sivas Turki, dilaporkan bahwa infestasi lebih tinggi terjadi pada kelompok usia 6-12 tahun. ${ }^{20}$ Hasil ini tidak memperlihatkan perbedaan pada kelompok usia lainnya. Hasil uji chi square menunjukkan tidak ditemukan adanya hubungan yang signifikan antara usia dengan infestasi P.h. capitis $(P>0,05)$. Hal ini berarti bahwa infestasi $P$.h. capitis dapat menyerang semua usia. Penelitian ini berbeda dengan penelitian yang dilakukan di Amerika Serikat di mana kelompok usia tertinggi untuk infestasi $P . h$. capitis adalah usia 3-11 tahun. ${ }^{8}$

Penelitian yang dilakukan oleh Azni SM pada tahun 2014 menyatakan bahwa infestasi meningkat seiring bertambahnya usia. Hal ini berhubungan dengan masalah higiene perorangan pada anak yang masih kecil yang biasanya masih berada dalam pengawasan orang tua khususnya ibu, namun seiring bertambahnya usia, pengawasan tersebut semakin berkurang. Hal ini menyebabkan infestasi P.h. capitis lebih tinggi ditemukan pada anak-anak yang lebih besar. ${ }^{21}$

\section{Jenis kelamin}

Hasil penelitian ini didapatkan infestasi P.h. capitis lebih tinggi terjadi pada anak perempuan sebesar $87,1 \%$. Penelitian ini sama dengan penelitian yang dilakukan oleh Zulinda A di Kota Pekanbaru pada tahun 2009 yaitu anak perempuan yang terinfestasi P.h. capitis sebesar $77,1 \%$ sedangkan laki-laki $8,1 \%{ }^{10}$ Beberapa penelitian lain juga menunjukkan hal yang sama. Penelitian oleh Rahman dan Malik di Semarang pada tahun 2014 didapatkan hasil sebesar $88,9 \%$ infestasi P.h. capitis terjadi pada perempuan sedangkan laki-laki sebesar $11,1 \%{ }^{16}$ Infestasi P.h. capitis di negara Thailand juga menunjukkan hasil yang sama di mana $47,12 \%$ infestasi terjadi pada anak perempuan dan $0 \%$ pada anak laki-laki.. ${ }^{22}$ Penelitian yang sama juga terjadi di negara Pakistan dengan hasil yang sama di mana infestasi pada anak perempuan lebih tinggi yaitu $64,78 \%$ dibandingkan pada anak laki-laki yaitu $35,22 \%{ }^{9}$

Uji statistik menggunakan model regresi logistik menunjukkan bahwa jenis kelamin berperan sebagai faktor risiko dominan terjadinya pedikulosis kapitis (Sig<0,05) dengan nilai Odds Ratio (OR) sebesar 6,9. 
Hal ini diartikan bahwa anak perempuan berisiko 6,9 kali lipat terinfestasi P.h. capitis dibandingkan dengan anak laki-laki. Hal ini dihubungkan dengan kebiasaan anak perempuan yang suka bermain bersama teman-temannya dalam kelompok kecil dan lebih sering mengalami kontak lebih dekat bersama temannya (head to head contact). Head to head contact merupakan jalur aktif untuk terjadinya transmisi P.h. capitis sedangkan penularan pasif dapat terjadi pada penggunaan bersama aksesoris seperti sisir dan jepit rambut. Kondisi inilah yang menyebabkan tingginya infestasi P.h. capitis pada anak perempuan dibandingkan anak laki-laki. ${ }^{23}$

\section{Karakteristik rambut}

Hasil pemeriksaan yang dilakukan terhadap jenis rambut dan panjang rambut didapatkan hasil untuk infestasi P.h. capitis pada jenis rambut lurus yaitu 48,9\%, ikal 76,9\%, dan keriting $81,8 \%$. Hasil ini menunjukkan bahwa infestasi tertinggi terjadi pada anak dengan jenis rambut yang keriting. Hasil ini sama dengan penelitian yang dilakukan oleh Nindia $Y$ pada tahun 2016 di kota Sabang yaitu tingkat infestasi $P$.h. capitis pada anak dengan jenis rambut lurus lebih rendah sebesar 20,2\% sedangkan infestasi tertinggi ada jenis rambut ikal sebesar $42,4 \%$ dan keriting $30,4 \%$.

Penelitian yang berbeda dilakukan oleh Witkowski menunjukkan bahwa jenis rambut lurus, ikal, dan keriting tidak mempengaruhi tingkat infestasi P.h. capitis.$^{24}$ Namun demikian, tekstur rambut yang lembut lebih disukai oleh P.h. capitis dari pada yang keras. Penelitian yang dilakukan pada orang kulit hitam lebih rendah dibandingkan orang kulit putih. Schold menyatakan bahwa orang kulit hitam memiliki rambut keriting dengan tekstur yang lebih keras, berbeda dengan orang kulit putih yang memiliki rambut lurus dan ikal dengan tekstur rambut yang lebih halus, sehingga infestasi P.h. capitis lebih tinggi pada orang dengan kulit putih dengan tekstur rambut yang lebih halus. ${ }^{25}$

Infestasi $P$.h. capitis di Indonesia lebih sering terjadi pada jenis rambut keriting, hal ini dihubungkan dengan tekstur rambut orang Indonesia yang secara umum serupa ${ }^{14}$ dan dinilai pada tingkat kelembaban di mana jenis rambut keriting lebih lembab jika dibandingkan dengan lurus dan ikal. Hal ini sesuai dengan tempat hidup dari P.h. capitis yang lebih suka hidup pada rambut yang lembab. ${ }^{4}$ Hasil uji chi square menunjukkan hasil yang signifikan antara jenis rambut dengan infestasi P.h. capitis dengan nilai OR sebesar 2,6. Hal ini berarti bahwa jenis rambut keriting berisiko 2,6 kali lipat untuk terinfestasi P.h. capitis dibandingkan dengan rambut ikal dan lurus.

Hasil penelitian panjang rambut terhadap infestasi P.h. capitis didapatkan hasil anak dengan panjang rambut $>$ sebahu infestasinya lebih tinggi dibandingkan dengan anak yang memiliki panjang rambut $\leq$ sebahu. Penelitian yang sama dilakukan oleh Zulinda A pada tahun 2009 di Rumbai Pesisir Pekanbaru, didapatkan hasil yaitu anak yang memiliki rambut panjang lebih tinggi terinfestasi $P . h$. capitis.$^{10}$ Hasil ini sama dengan penelitian yang dilakukan oleh Nindia Y tahun 2016 di mana anak yang memiliki panjang rambut lebih dari sebahu terinfestasi P.h. capitis sebesar $51,6 \%{ }^{6}$ Penelitian ini tidak jauh berbeda dengan penelitian yang dilakukan oleh Rahman tahun 2014 yaitu infestasi P.h. capitis tinggi pada anak dengan rambut panjang sebesar $59,3 \% .^{16}$

Hasil uji statistik menggunakan model regresi logistik didapatkan hasil yang signifikan dengan nilai OR sebesar 3,5. Hal ini berarti bahwa panjang rambut > sebahu berisiko 3,5 kali lipat untuk terjadi infestasi P.h. capitis dibandingkan dengan panjang rambut $\leq$ sebahu. Hal ini berhubungan erat dengan cara merawat rambut kepala baik dari segi frekuensi cuci rambut, kebiasaan mengikat rambut, dan memakai kerudung.

Anak perempuan di Panti Asuhan di Kota Pekanbaru umumnya menggunakan kerudung saat berada di sekolah. Penggunaan kerudung (jilbab) mungkin dapat membatasi transmisi P.h. capitis dari satu anak perempuan ke temannya, namun transmisi P.h. capitis dapat terjadi pada saat bermain di luar jam sekolah. Kondisi rambut dari kulit kepala cenderung menjadi lebih lembab terutama pada anak dengan rambut panjang yang diikat ketika menggunakan kerudung, rambut yang basah setelah keramas juga membuat kondisi rambut menjadi lembab. Kondisi inilah yang disukai oleh P.h. capitis untuk berkembang sehingga infestasinya dapat meningkat. ${ }^{6}$

\section{Perilaku higiene}

\section{a. Frekuensi cuci rambut}

Hasil pemeriksaan yang telah dilakukan didapatkan hasil anak yang mencuci rambut dengan frekuensi $\geq$ 3 kali dalam seminggu lebih tinggi infestasinya untuk terjadi pedikulosis kapitis dibandingkan dengan anak yang mencuci rambut $<3$ kali dalam seminggu. Hasil uji chi square menunjukkan hasil yang tidak signifikan $(P>0,05)$. Penelitian ini sejalan dengan 
penelitian yang dilakukan Akhmad AM pada tahun 2012 didapatkan hasil frekuensi cuci rambut tidak mempengaruhi infestasi P.h. capitis ${ }^{17}$

Penelitian lain yang memberikan hasil berbeda yaitu penelitian yang dilakukan oleh Nindia $Y$ tahun 2016 yaitu anak yang hanya mencuci rambut 2 minggu sekali didapatkan hasil 42,2\% lebih tinggi terinfestasi P.h. capitis . ${ }^{6}$ Perbedaan hasil ini dikarenakan masih banyak faktor risiko yang dapat meningkatkan kejadian pedikulosis kapitis, sehingga untuk infestasi $P . h$. capitis juga harus dilihat dari semua faktor risiko yang ada. Anak Panti Asuhan di Kota Pekanbaru yang mencuci rambut $\geq 3$ kali dalam seminggu banyak yang memiliki rambut panjang lebih dari sebahu, sehingga dengan faktor risiko panjang rambut inilah yang mungkin menjadi tingginya infestasi $P$.h. capitis pada anak yang mencuci rambut $\geq 3$ kali dalam seminggu.

\section{b. Pemakaian alat rambut bersama dan kebiasaan tidur bersama}

Penelitian terhadap anak yang memakai alat rambut bersama dan mempunyai kebiasaan tidur bersama terinfestasi P.h. capitis sebesar 57,5\%, sedangkan anak yang juga memiliki kebiasaan menggunakan alat rambut bersama dan kebiasaan tidur bersama yang tidak terinfestasi P.h. capitis sebesar $42,5 \%$. Angka tersebut menunjukkan perbedaan yang tidak signifikan di mana anak yang memiliki kebiasaan yang sama tidak menunjukkan infestasi P.h. capitis. Penelitian ini berbeda dengan penelitian yang dilakukan oleh Rahman pada tahun 2014S yaitu dari 48 responden yang diperiksa, didapatkan hasil 27 orang memiliki kebiasaan memakai alat rambut atau tidur bersama dan persentase $34,5 \%$ terinfestasi $P . h$. capitis, sedangkan 21 orang lainnya yang tidak memiliki kebiasaan menggunakan alat rambut

\section{DAFTAR PUSTAKA}

1. 1. Djuanda A, Kosasih A, Wiryadi B.E, Natahusada EC, Daili ES, Effendi EH, et al. IImu penyakit kulit dan kelamin. Cet 3. Jakarta: Fakultas kedokteran Universitas Indonesia; 2013. 119-120.

2. Feldmeier $\mathrm{H}$, Heukelbach J. Epidermal parasitic skin disease. Bull world health orga. 2009;87:152-159.

3. Doroodgar A, Sadr F, Doroodgar M, Doroodgar Mo, Sayyah M. Examining the prevalence rate of pediculus capitis infestation according to sex and social factors in primary school children. Asian Pac J Trop Disc. 2014;4(1):25-29.

4. Soedarto. Buku ajar parasitologi kedokteran. Jakarta: Sagung seto; 2011.256-259.

5. Moosazadeh $M$, Afshari $M$, Keianian $H$, Nezammahalleh A, Enayati A.A. Prevalence of head lice infestation and its associated factors among primary bersama atau tidur bersama tidak terinfestasi P.h. capitis.${ }^{16}$ Hasil uji chi square tidak dapat dilakukan karena tidak memenuhi syarat tabel minimal $2 \times 2$.

\section{SIMPULAN}

Karakteristik anak panti asuhan di kota Pekanbaru terbanyak pada kelompok usia 13-18 tahun, jenis kelamin laki-laki. Faktor risiko jenis rambut terbanyak yaitu lurus, panjang rambut terbanyak $\leq$ sebahu, dan semua anak Panti Asuhan di Kota Pekanbaru pernah memakai alat rambut bersama dan tidur bersama. Angka kejadian infestasi P.h. capitis pada anak Panti Asuhan di Kota Pekanbaru masih tergolong tinggi. Infestasi P.h. capitis berdasarkan faktor risiko tertinggi pada kelompok usia 6-12 tahun. Jenis kelamin terbanyak perempuan, jenis rambut yang sering terinfestasi P.h. capitis adalah keriting dengan panjang rambut $>$ sebahu. Frekuensi cuci rambut $\geq 3$ kali seminggu dan kebiasaan tidur bersama serta pemakaian alat rambut bersama lebih sering terinfestasi $P$.h. capitis. Faktor risiko yang mempengaruhi tingkat infestasi P.h. capitis secara signifikan adalah jenis kelamin, panjang rambut, dan jenis rambut dengan nilai $p$ value $<0,05$. Faktor risiko lainnya seperti kelompok usia, frekuensi cuci rambut tidak memiliki pengaruh yang signifikan terhadap peningkatan infestasi P.h. capitis. Faktor risiko Pemakaian alat rambut bersama dan kebiasaan tidur bersama tidak dapat dinilai hubungan variabel karena tidak memenuhi syarat tabel $2 \times 2$.

\section{KONFLIK KEPENTINGAN}

SDL merupakan salah satu anggota editor, namun tidak terlibat dalam proses review artikel ini.

school students in Iran: a systematic review and metaanalysis. Osong Public Health Res Perspect. 2015;6(6):346-356.

6. Nindia Y. Prevalensi infestasi kutu kepala (pediculus humanus capitis) dan faktor risiko penularannya pada anak sekolah dasar di kota Sabang provinsi Aceh [tesis]. Bogor: Institut Pertanian Bogor (IPB); 2016.

7. Centers for Disease Control and Prevention (CDC). Pediculosis. (Cited 2017 May 28); Available from: https://www.cdc.gov/dpdx/pediculosis/.

8. Centers for Disease Control and Prevention (CDC). Head lice. (Cited 2017 May 28); Available from: https://www.cdc.gov/parasites/lice/head/epi.html.

9. Lashari MH, Sial N, Akhtar MS, Siddique F, Nawaz M, Yousaf $M$, et al. Prevalence of head lice among school children. Gomal J Med Sci. 2015;13(4):239-242. 
10. Zulinda A. Faktor-faktor yang mempengaruhi kejadian pedikulosis kapitis pada murid kelas III,IV, V, dan VI SDN 019 Tebing Tinggi Okura Kecamatan Rumbai Pesisir Pekanbaru [skripsi]. Pekanbaru: Universitas Riau (UR); 2009.

11. Natadisastra D. Penyakit parasit pada dermatomuskuloskeletal. Dalam: Natadisastra D, Agoes R, editors. Parasitologi kedokteran: ditinjau dari organ tubuh yang diserang. Jakarta: EGC;2009.295296.

12. Elmonia CM. Hubungan antara attachment pada pengasuh dengan self-disclosure remaja di panti sosial asuhan anak wisma putra Bandung [skripsi]. Bandung: Fakultas IImu Pendidikan Universitas Pendidikan Indonesia (UPI);2015.

13. Peraturan Menteri Sosial Republik Indonesia. Standar nasional pengasuhan anak untuk lembaga kesejahteraan sosial anak. 2011 (dikutip 28 Desember 2017).

14. Zhen AJ, Murhandarwati EEH, Umniyati SR. Head lice infestation and its relationship with hygiene and knowledge among urban school children in Yogyakarta. TMJ. 2014;01(01): 35-41.

15. Munusamy $\mathrm{H}$, Murhandarwati EEH, Umniyati SR. The relationship between the prevalence of head lice infestation with hygiene and knowledge among the rural school children in Yogyakarta. TMJ. 2014;01(02):102-109.

16. Rahman ZA. Faktor-faktor yang berhubungan dengan kejadian Pediculosis capitis pada santri pesantren rhodlotul quran Semarang [skripsi]. Semarang: Universitas Diponegoro;2014.

17. Akhmad AM, Menaldi SL. Prevalensi pedikulosis kapitis dan hubungan tingkat infestasi dengan karakteristik santri putri pesantren X, Jakarta Timur [Internet]. 2012 (Dikutip 18 Oktober 2017)

18. Dinas komunikasi informatika statistik dan persandian kota Pekanbaru. Wilayah geografis.2017. [Dikutip 20 November 2017] Diakses pada: http://www.pekanbaru.go.id/wilayah-geografis/

19. Abdulla BS. Morphological study and prevalence of head lice (Pediculus humanus capitis) (Anoplura: Pediculidae) Infestation among some primary school students in Erbil City, Kurdistan Region. Zanco J Pure Appl Sci [Internet]. 2015 (Cited 2017 June 09);27(5):2936.

20. Degerli S, Malatyali E, Celiksoz A, Ozcelik S, Mumcuoglu KY. The prevalence of Pediculus humanus capitis and the Coexistence of Intestinal Parasites in young children in boarding schools in Sivas, Turkey. Pediatric Dermatology [Internet]. 2012 (Cited 2017 June 09);29(4):426-429.

21. Azni SM. Prevalence of head lice at the primary schools in Damghan. Zahedan J Res Med Sci [Internet]. 2014 (Cited 2017 Oct 18);16(11): 47-49.

22. Akturk AS, Ozkan O, Godkemir M, Tecimer S, Bilen N. The prevalence of pediculosis capitis and factors related to the treatment success in primary school children and their family members in Kocaeli. TAF Prev Med Bull [Internet]. 2012 (Cited 2017 Oct 18);11(2): 181-190.

23. Rassami W, Soonwera M. Epidemiology of pediculosis capitis among schoolchildren in the eastern area of Bangkok, Thailand. Asian Pac J Trop Biomed [Internet]. 2012 (Cited 2017 Nov 18);2(11): 901-904.
24. Witkowski JA, Parish LC. Pthiriasis capiti. Int J Dermatol 1979;18:559.

25. Schold LL, Holloway, Farouk WD. The epidemiology of human pediculosis in Ethiopia. Special publication US Navy, Disease vector ecology control centre;1979. 